Kostenko V, Balazh M. Organization of rehabilitation care for patients with ischemic heart disease at the outpatient stage: problems and prospects. Theory and Methods of Physical education and sports. 2020; 1: 61-67

DOI: $10.32652 /$ tmfvs.2020.1.61-67
Костенко В, Балаж М. Організація реабілітаційної допомоги хворим на ішемічну хворобу серця на амбулаторному етапі: проблеми та перспективи. Теорія і методика фрізичного виховання і спорту. 2020; 1: 61-67

DOI: $10.32652 /$ tmfvs.2020.1.61-67

\title{
ОРГАНІЗАЦІЯ РЕАБІЛІТАЦІЙНОЇ ДОПОМОГИ ХВОРИМ НА ІІЕМІЧНУ ХВОРОБУ СЕРЦЯ НА АМБУЛАТОРНОМУ ЕТАПІ: ПРОБЛЕМИ ТА ПЕРСПЕКТИВИ
}

\section{Владислав Костенко, Марія Балаж}

Національний університет фізичного виховання і спорту України, Київ, Україна

\begin{abstract}
Анотація. Кардіореабілітація, заснована на фізичних тренуваннях та корекції факторів ризику серцевосудинних захворювань, $€$ одним із найважливіших засобів покращення прогнозу у хворих на ішемічну хворобу серця. В Україні абсолютна більшість кардіологічних пацієнтів не отримують переваг кардіореабілітації. Недостатнє впровадження сучасних програм кардіореабілітації на амбулаторному етапі лікування є нагальною проблемою в Україні.
\end{abstract}

Mета. Розглянути сучасні підходи до організації реабілітаційної допомоги хворим на ішемічну хворобу серця на амбулаторному етапі. Методи. Аналіз та узагальнення даних зарубіжної та вітчизняної наукової літератури. Результати. Система реабілітації серцево-судинних хворих, яка сьогодні діє в Україні, є застарілою та небезпечною. Велика кількість ускладнень серед кардіологічних пацієнтів пов'язана з фрактичною відсутністю надання ефективної реабілітаційної допомоги хворим на ішемічну хворобу серця після їх виписки зі стаціонарного відділення. Розробка та впровадження новітніх кардіореабілітаційних програм з урахуванням зарубіжного досвіду та національного контексту дозволить продовжувати реабілітацію хворих на ішемічну хворобу серця на амбулаторному етапі та знизити відсоток ускладнень і летальності серед тематичного контингенту. Численні дослідження продемонстрували важливість кардіореабілітації у профрілактиці та лікуванні ішемічної хвороби серця. Недостатнє впровадження сучасних програм кардіореабілітації в Україні призводить до високого поширення фракторів ризику, пов'язаних з коронарними чинниками, та високої летальності серед кардіологічних пацієнтів. Для вирішення цієї проблеми потрібен комплекс інституційних перетворень та змін у політиці у сфері охорони здоров'я і соціального захисту населення. Велика увага має бути приділена організації ефективного надання кардіореабілітаційної допомоги на амбулаторному етапі, що дозволить більш ефективно контролювати кардіометаболічні фрактори ризику і підвищувати прихильність пацієнтів до лікування.

Ключові слова: кардіореабілітація, кардіопрофілатика, фрізична терапія, фрізичні тренування, ішемічна хвороба серця.

\section{Vladyslav Kostenko, Mariia Balazh}

\section{ORGANIZATION OF REHABILITATION CARE FOR PATIENTS WITH ISCHEMIC HEART DISEASE AT THE OUTPATIENT STAGE: PROBLEMS AND PROSPECTS}

\begin{abstract}
Cardiac rehabilitation, based on physical training and correction of risk factors for cardiovascular diseases, is one of the most important means for improving the prognosis in patients with ischemic heart disease. In Ukraine, the vast majority of cardiac patients do not receive the benefits of cardiac rehabilitation. Insufficient implementation

of modern cardiorehabilitation programs at the outpatient stage of treatment is an urgent problem in Ukraine. Objective. To consider modern approaches to the organization of rehabilitation care for patients with ischemic heart disease at the outpatient stage. Methods. Analysis and generalization of data from foreign and domestic scientific literature. Results. The system of rehabilitation of cardiovascular patients, which currently operates in Ukraine, is outdated and dangerous. A large number of complications among cardiac patients are due to a lack of effective rehabilitation care for patients with ischemic heart disease after their discharge from the inpatient department. Development and implementation of the latest cardiorehabilitation programs with account for foreign experience and national context will allow to continue rehabilitation of patients with ischemic heart disease at the outpatient stage and reduce the percentage of complications and mortality among the thematic contingent. Numerous studies have demonstrated the importance of cardiorehabilitation in the prevention and treatment of ischemic heart disease. Insufficient implementation of modern cardiac rehabilitation programs in Ukraine leads to high prevalence of risk factors associated with coronary factors and high mortality among cardiac patients. This problem requires a set of institutional changes and alterations in health and social protection policies. Much attention should be paid to the organization of effective outpatient cardiorehabilitation care, which will allow more effective control of cardiometabolic risk factors and increase patient adherence to treatment.
\end{abstract}

Keywords: cardiorehabilitation, prevention, physical therapy, physical training, ischemic heart disease. 
Вступ. Згідно з офіційною статистикою, провідними факторами смертності працездатного населення у світі є серцево-судинні захворювання (СС3), що посідають перше місце в структурі неінфекційних хвороб, на які припадає близько 70 \% смертей. СС3 викликають 16,5-17,5 млн летальних випадків щороку, що перевищує летальність внаслідок новоутворень, зовнішніх причин тощо. Згідно з аналізом експертів ВОО3, очікуваний рівень смертності внаслідок серцево-судинної патології у 2030 р. становитиме 24,1-24,3 млн осіб [6].

Серед мешканців України СС3 є лідерами за своєю поширеністю і первинною захворюваністю та головною причиною смертності її населення. Ці патології реєструються у 57,5 \% жителів, що становить 26,4 млн хворих, у тому числі 9,6 млн. осіб працездатного віку. ССЗ щорічно спричиняють інвалідність у близько 15 осіб на 10 тис. дорослого населення України, вони є причиною смерті 160 тис. осіб [3].

Згідно з даними ВООЗ та Всесвітньої організації серця, в рейтингу смертності від серцевосудинних захворювань Україна посідає провідні позиції як у Європі, так і у світі [6]. Найбільше соціально-економічне значення серед СС3 мають ішемічна хвороба серця (IXC), інсульт, артеріальна гіпертензія (АГ), та серцева недостатність, 3 якими пов'язано $82 \%$ смертей [1, 5].

Саме тому одним з пріоритетних завдань системи охорони здоров'я є пошук ефективних методів лікування та профілактики СС3, зокрема, IXC. Особливе місце в цьому процесі належить кардіореабілітації. Комплексні програми реабілітації, що включають окрім медикаментозної терапії та фізичних тренувань заходи з модифікації способу життя, контроль кардіометаболічних факторів ризику та освітні програми, включені до національних рекомендацій, опублікованих багатьма кардіологічними асоціаціями. Поняття серцевої реабілітації, або кардіореабілітації вже міцно ввійшло в кардіологічну практику лікарів більшості країн світу. Доведено, що кардіореабілітація, заснована на фізичних тренуваннях та корекції факторів ризику СС3, є одним із найважливіших та економічно доцільних засобів покращення прогнозу у хворих на IXC. Кардіореабілітація після СС3 належить до доказового класу 1, згідно 3 рекомендаціями Свропейської спілки кардіологів (ESC), Американської асоціації серця (АНА), Американського кардіологічного коледжу (АСС) [14]. Однак, незважаючи на доведені переваги кардіореабілітації, частота використаних реабілітаційних можливостей залишається не оптимальною [4].

За результатами третього дослідження EUROASPIRE, що були опубліковані в Європейському журналі превентивної кардіології, значна частина європейців 3 ішемічною хворобою серця не отримують всіх переваг кардіологічних реабілітаційних служб, реабілітаційні служби Свропи не використовуються повною мірою через недостатню кількість направлень.

Найвищі показники участі в реабілітаційних програмах було зареєстровано в Литві та Ірландії, найнижчі - в Туреччині, Росії та на Кіпрі, відсутність реабілітації - в Греції та Іспанії. У Франції 32,4 \% пацієнтам з IXC було рекомендовано взяти участь у реабілітаційних програмах, 90 \% із них дотрималися цієї рекомендації. У Німеччині ці показники становлять відповідно 56,6 та 91,1 \%; в Італії 51,5 та 88,7 \%; у Великій Британії 43 та $80,6 \%$; в Іспанії 3 та $1 \%$.

Порівняння даних, які були отримані в 13 країнах, що брали участь у другому і третьому дослідженні EUROASPIRE, показало, що кількість пацієнтів, яким було рекомендовано кардіологічну реабілітацію, зросла 3 44,5 до 55,7 \%; також 3 38 до $46 \%$ зросла кількість осіб, які взяли участь у реабілітаційних програмах [4]. За результатами дослідження EUROASPIRE IV, загальна тенденція участі хворих у реабілітаційних програмах виявилася схожою в Україні та Свропі: сеанси реабілітації відвідували лише близько половини (51%) європейських пацієнтів і менше половини (44\%) українців. Однак прихильність до даних програм в Україні виявилася істотно нижчою, ніж в Свропі, оскільки тільки кожен четвертий $(28,5$ \%) відвідав половину сесій реабілітації. В Свропі половину занять в середньому відвідали 81 \% хворих [2].

Таким чином, в Україні більшість кардіологічних пацієнтів не отримують переваг кардіореабілітації, що обумовлено рядом соціально-економічних факторів. Фізичний аспект реабілітації хворих на IXC в Україні значно відстає від медикаментозної корекції, особливо на амбулаторному етапі лікування. Слід підкреслити, що фактична відсутність амбулаторної кардіореабілітації призводить до високого поширення факторів ризику, пов'язаних 3 коронарними подіями та низьким рівнем фізичної активності пацієнтів після індексних подій. Тому вирішення проблеми організації надання реабілітаційної допомоги кардіологічним хворим на амбулаторному етапі є однією з нагальних проблем в Україні.

Роботу виконано відповідно до плану НДР НУФВСУ на 2016-2020 рр. за темою 4.2. «Організаційні та теоретико-методичні основи фізичної реабілітації осіб різних нозологічних, професійних та вікових груп» (номер держреєстрації 0116U001609).

Мета дослідження - розглянути сучасні підходи до організації реабілітаційної допомоги хворим на ішемічну хворобу серця на амбулаторному етапі.

Методи дослідження: аналіз та узагальнення даних зарубіжної та вітчизняної наукової літератури.

Результати дослідження та їх обговорення. Всесвітня організація охорони здоров'я запропо- 
нувала визначення, згідно з яким кардіореабілітація - це комплекс послідовних заходів, що впливають на вихідні причини захворювань, підвищують ефективність терапії, а також забезпечують створення найкращих фізичних, психологічних i соціальних умов для збереження і відновлення соціального статусу пацієнта [4].

Провідні кардіологічні товариства (American Heart Association, American Collage of Cardiology Foundation) визначили основні компоненти сучасної кардіореабілітації, яка повинна включати оцінку стану пацієнта, фізичні тренування, консультації пацієнта з фізичної активності, з питань харчування, контролю ваги, відмови від куріння, агресивне управління факторами ризику, пов'язаними 3 коронарними подіями, психосоціальне консультування, а також, за необхідності, консультації 3 проблем вживання алкоголю і управління стресами.

Серед завдань, що стоять перед фахівцями 3 кардіореабілітації, можна виділити короткострокові та довгострокові. До найбільш важливих короткострокових завдань прийнято відносити стабілізацію СС3 та забезпечення контролю над його симптомами, відновлення оптимального фізичного та психічного стану, необхідного для повернення пацієнта до звичного способу життя, зниження ризику рецидиву захворювання, покращення якості життя.

Довгострокові цілі кардіореабілітації - виявлення та усунення факторів ризику, стабілізація та запобігання прогресуванню атеросклеротичного процесу, зниження захворюваності та смертності.

Не дивлячись на те що ключові компоненти i мета кардіореабілітації визначені у відповідних регламентних документах, особливості програм реабілітації дуже варіюють у різних країнах. Традиції системи охорони здоров'я і дотації на неї відіграють ключову роль. У ряді європейських країн програма реабілітації включає 2-3-тижневе перебування пацієнта, коли він знаходиться поза своїм звичайним оточенням, в ідеальних умовах, зі всіма необхідними медикаментами і навчанням здорового способу життя, з наступним продовженням навчання в амбулаторних умовах. В інших країнах здійснюється реабілітація в амбулаторних умовах, коли пацієнт один-два рази на тиждень протягом кількох місяців бере участь у заняттях 3 реабілітації, спрямованих на зміну способу життя в своєму звичайному оточенні, у тому числі і після повернення з роботи [4].

У більшості європейських країн та у США процес кардіореабілітації традиційно поділяють на чотири етапи, що послідовно змінюють один одного.

Перший етап зазвичай полягає у роз'ясненні пацієнту, який переніс гостру коронарну подію, сутності його захворювання. У більшості випадків у цей час пацієнт тривожний, нерідко знаходиться в депресивному стані. Саме тому основними завданнями цього етапу кардіореабілітації є інфор- мування та надання психологічної підтримки. Під час першого етапу кардіореабілітації оцінюють наявні у пацієнта фактори ризику, надають йому інформацію про захворювання, модифікацію факторів ризику та здоровий спосіб життя. Це найкоротший за тривалістю етап, переважно він триває три-чотири дні або до стабілізації стану пацієнта.

Під час другого етапу кардіореабілітації складають план наступного лікування та обстеження пацієнта, з ним обговорюють подальший перебіг захворювання. Наприкінці цього етапу, перед виписуванням пацієнта зі стаціонару, рекомендують провести тест для визначення толерантності до фізичного навантаження.

Третій етап кардіореабілітації триває до 613-го тижня після гострої коронарної події. Найчастіше це стадія формального початку реабілітаційної програми, що включає фізичні тренування та освітні заходи. Фізичні навантаження стають основними компонентами реабілітації на даному етапі, проте психосоціальна підтримка, консультації про фактори ризику та принципи здорового способу життя залишаються його невід'ємною та важливою частиною.

Четвертий етап кардіореабілітації розрахований на тривалий період часу, момент його завершення не встановлюють. На цьому етапі пацієнт продовжує самостійно виконувати програму фізичних тренувань і модифікації факторів ризику, періодично зустрічаючись із фахівцями для обстеження та консультацій. Таким чином досягають індивідуальних для кожного пацієнта цілей, поставлених на попередніх етапах реабілітації.

В українській клінічній практиці до сьогодні не було прийнято виділяти такі етапи кардіореабілітації, проте можна простежити певну схожість у базових підходах до організації надання реабілітаційної допомоги кардіологічними хворим із європейськими.

Система реабілітації серцево-судинних хворих, яка сьогодні діє в Україні, була створена ще у 1970-1980-ті роки та передбачає поступове розширення рухової активності хворих відповідно до семи ступенів з дотриманням конкретних критеріїв розширення режиму за схемою: стаціонар-санаторій-диспансерно-поліклінічне спостереження [7]. Ця ступінчаста система рухової активності у свій час дозволяла активізувати хворого, починаючи 3 блоку інтенсивної терапії та готувати його до переведення до відділення реабілітації місцевого санаторію прямо зі стаціонару з дотриманням конкретних критеріїв розширення режиму. Під час виписки зі стаціонару пацієнт, який переніс гострий інфаркт міокарда, повинен був проходити в два-три прийоми дистанцію до 1,5-2 км, підніматися на один-два поверхи і бути повністю здатним до самообслуговування. У санаторії пацієнти повинні були досягти заключного - VII - ступеня рухової активності і за своїми фізичними можливостями відповідати практично здоровій нетре- 
нованій людині такої самої статі і віку, тобто мали бути виписані придатними до праці.

В останні роки 3 розвитком фармацевтичної i кардіохірургічної служби збільшилася кількість успішних інвазивних і хірургічних втручань на судинах серця хворим із гострим інфарктом міокарда, що сприяло скороченню термінів госпіталізації, більш швидкому обороту ліжок в кардіологічних відділеннях і ранній виписці хворих на амбулаторний етап. При цьому хворі освоюють II, рідше III ступінь рухової активності (ходьба по палаті, вихід в коридор) і абсолютно не готові до умов санаторію. Їх переводять до відділень реабілітації санаторіїв, де фактично просто знаходяться на півпостільному режимі, досягаючи до кінця перебування там IV, рідше V ступеня активності.

У результаті порушення встановлених раніше умов прийому хворих до санаторіїв серед них виросло число серйозних ускладнень і летальних випадків. Проте слід підкреслити, що для більшості кардіологічних пацієнтів в Україні через економічні причини санаторне лікування взагалі недоступне. Після виписування зі стаціонару такі хворі одразу повертаються додому, де через низьку функціональну здатність стають залежними від піклувальників або ж змушені виконувати побутові навантаження, до яких вони не готові функціонально, що також стає причиною ускладнень та летальних випадків.

Таким чином, наявна система кардіореабілітації демонструє свою недосконалість та небезпечність. 3 іншого боку, створення ефективної системи кардіореабілітації, яка охоплює як ранні, так і пізні її етапи, дозволить більш ефективно контролювати кардіометаболічні фактори ризику і стимулювати пацієнтів до виконання рекомендацій фахівців до здорового способу життя і лікування. В Україні найбільша проблема вбачається у фактичній відсутності амбулаторної реабілітації кардіологічних пацієнтів. Варто зазначити, що проблема ефективної організації надання реабілітаційної допомоги кардіологічним хворим в амбулаторних умовах не є унікальною для України. В європейських країнах та США саме на амбулаторному етапі спостерігається суттєве зниження частки пацієнтів, залучених до кардіореабілітаційних програм, що спонукало зарубіжних фахівців до інтенсивного пошуку шляхів вирішення даної проблеми [4].

У Європі та США пацієнтів виписують після завершення другого (інколи першого) етапу кардіореабілітації. Тобто вирішення завдань із залучення пацієнтів до тривалої програми тренувань із фізичним навантаженням та корекції кардіометаболічних факторів ризику найчастіше має здійснюватися в амбулаторних умовах. Зазвичай, за кордоном фізичні тренування третього етапу кардіореабілітації проводять на базі медичних закладів або фітнес-центрів під контролем медичного персоналу, проте в останні роки спостерігається тенденція до проведення фізичних тренувань в домашніх умовах після попереднього навчання пацієнтів прийомів самоконтролю. Проведення застосування кардіореабілітації в домашніх умовах обумовлене ефективністю та доступністю таких програм. Через те що значна частина хворих, котрим рекомендовані контрольовані тренування, не в змозі брати в них участь через різні причини (далека відстань, обмеженість часу занять у реабілітаційних центрах, небажання хворого), розробка програми індивідуальних занять у домашніх умовах сприяє формуванню у пацієнтів прихильності до її виконання [17].

Посиленому впровадженню домашніх програм кардіореаблітації сприяє розвиток телемедичних технологій. Останні дослідження демонструють, що такі програми за ефективністю не поступаються програмам, які реалізуються на базі медичних закладів [9, 11, 15, 16]. Окрім того, зарубіжні дослідження показали, що домашня телекардіореабілітація є більш ефективною для підтримання працездатності пацієнтів та має меншу вартість лікування, ніж кардіореабілітація на базі лікарні [8, 12, 20, 21].

Зауважимо, що існують певні обмеження в застосуванні домашньої кардіореабілітації. Ця модель здебільшого є доступною для кардіологічних пацієнтів груп низького та середнього ризику [18]. Проведення занять у домашніх умовах вимагає постійного зв'язку з фізичними терапевтами та медсестрами для регулярного управління навчанням, контролю та спостереження за пацієнтами 3 метою усунення сумнівів, непорозумінь або потенційних афективних розладів під час виконання фізичних вправ. Це ставить більший виклик 3 точки зору відповідальності та терпіння з боку медичного персоналу та керівництва лікарні. Також для безпеки фізичних вправ та запобігання нещасним випадкам, пацієнти, які займаються вдома, потребують супроводу членів родини під час тренувань.

В останні роки у західних країнах отримали розвиток такі моделі амбулаторної кардіореабілітації, як інтерактивні програми на базі смартфонів та соціальних медіа $[10,13]$, а також реабілітація на базі громад (community-based rehab). Ці моделі є достойними альтернативами до кардіореабілітації на базі лікарні, оскільки вони ефективні щодо зниження факторів ризику СС3 і при цьому дозволяють зменшити економічне навантаження на пацієнтів [19].

3 огляду на досвід інших країн та національний контекст, шляхами вирішення проблеми амбулаторної реабілітації кардіологічних пацієнтів в Україні можуть бути такі напрями:

- організація спеціально перепрофільованих відділень для доліковування хворих після гострих коронарних подій, куди через 7-15 днів будуть переводитися хворі. Ці відділення легко можуть 
бути створені шляхом перепрофілювання ліжкового фонду за рішенням місцевих органів охорони здоров'я;

- повноцінне використання наявних санаторіїв кардіологічного профілю, що дозволить збільшити тривалість контрольованих занять після перенесеної гострої коронарної події та проводити більш ефективне навчання пацієнтів і їх підготовку до подальших етапів кардіореабілітації;

- створення центрів кардіореабілітації, що мають стаціонарний і диспансерний відділи, для надання спеціалізованої допомоги в стаціонарному відділенні реабілітаційного центру на ранніх етапах і у фазі одужання в межах 2-3-го місяця хвороби в амбулаторних умовах;

- широке впровадження таких новітніх кардіореабілітаційних технологій, як телемедицина, телемоніторинг, інтерактивні програми на базі смартфонів, програми віртуальної реальності тощо, що дозволить організувати надання кардіореабілітаційної допомоги в домашніх умовах та забезпечити непереривність процесу кардіореабілітації.
Висновки. Численні дослідження продемонстрували важливість кардіореабілітації у профілактиці та лікуванні IXC. Недостатнє впровадження сучасних програм кардіореабілітації в Україні призводить до високого поширення факторів ризику, пов'язаних з коронарними подіями та високої летальності серед кардіологічних пацієнтів. Для вирішення цієї проблеми потрібен комплекс інституційних перетворень та змін у сфері охорони здоров'я і соціального захисту населення. Велика увага має бути приділена організації ефективного надання кардіореабілітаційної допомоги на амбулаторному етапі, що дозволить більш ефективно контролювати кардіометаболічні фактори ризику і підвищувати прихильність пацієнтів до лікування.

Перспективи подальших досліджень передбачають впровадження новітніх кардіореабілітаційних технологій у практику охорони здоров'я i вивчення їх впливу на показники поширеності серцево-судинних захворювань.

Конфлікт інтересів. Автори заявляють, що відсутній будь-який конфлікт інтересів.

\section{Література}

1. Іпатов АВ, Лисунець ОМ, Ханюкова ІЯ, Ткаченко ЮВ, Овдій ОМ, Зубко ІМ. Первинна інвалідність внаслідок провідних хвороб системи кровообігу в Україні. Буковинський медичний вісник. 2017; 21 (2):197-202.

2. Коваленко ВН, Долженко МН, Несукай ЕГ, Дьяченко ЯС. Сравнительная характеристика профилактики сердечно-сосудистых заболеваний в Украине и Еропе по данным EUROASPIRE IV: госпитальная линия. Артериальная гипертензия. 2015; 5(43):57-61.

3. Корнус ОГ, Корнус АО, Шищук ВД, Логвин ГО. Первинна захворюваність і поширеність хвороб системи кровообігу та їх роль як причин смертності населення Сумської області.[Internet]. Scientific Notes of Sumy State Pedagogical University. Geographical Sciences. 2020; 2 (1): 97-111. Available from: http://scinotesgeo.at.ua/ Vol2_Iss1/Kornus_O.H-Kornus_A.O-Shyshchuk_V.D-Lohvyn_H.O-Pri.pdf. DOI: doi.org/10.5281/zenodo.3661431

4. Корчинський ВС. Кардіореабілітація: сучасний стан та пріоритети розвитку. Вісник Вінницького національного медичного університету. 2015; 1 (19): 244-7.

5. Хиць А. Ішемічна хвороба серця: діагностика та лікування. [Інтернет]. Український медичний часопис. 2019. Режим доступу: https://www.umj.com.ua/article/163681/ishemichna-hvoroba-sertsya-diagnostika-talikuvannya

6. Шапошніков ДІ, Радомський ОВ, Бєлікова IB, Костріков АВ. Аналіз епідеміологічної ситуації щодо хвороб системи кровообігу в Україні та Пакистані. 2019. [Інтернет]. Режим доступу: http://elib.umsa.edu.ua/bitstream/ umsa/10304/1/Analysis_of_the_epidemiological_situation.pdf

7. Швед МІ, Левицька Л̄B. Сучасні стратегії лікування та реабілітації хворих на інфраркт міокарда. Київ. 2015. $152 \mathrm{c}$.

8. Bravo-Escobar R, Gonzalez-Represas A, Gomez-Gonzalez AM. Montiel-Trujillo A, Aguilar-Jimenez R, Carrasco-Ruiz R, Salinas-Sanchez P. Effectiveness and safety of a homebased cardiac rehabilitation programme of mixed surveillance in patients with ischemic heart disease at moderate cardiovascular risk: A randomised, controlled clinical trial. BMC Cardiovasc Disord 2017. 17: 1-11.

9. Chan C, Yamabayashi C, Syed N, Kirkham A, Camp PG. Exercise Telemonitoring and Telerehabilitation Compared with Traditional Cardiac and Pulmonary Rehabilitation: A Systematic Review and Meta-Analysis. Physiother Can. 2016. 68(3): 242-51.

10. Dorje T, Zhao G, Scheer A, Tsokey L, Wang J, Chen Y, Tso K, Tan BK, Ge J, Maiorana A. SMARTphone and social media-based cardiac rehabilitation and secondary prevention (SMART-CR/SP) for patients with coronary heart disease in China: a randomised controlled trial protocol. BMJ Open. 2018; 8, 1-9.

11. Gensini GF, Alderighi C, Rasoini R, Mazzanti M, Casolo G. Value of Telemonitoring and Telemedicine in Heart Failure Management. Card Fail Rev.2017; 3(2),116-121. doi: 10.15420/cfr.2017:6:2.

12. Hwang R, Morris NR, Mandrusiak A, Bruning J, Peters R, Korczyk D, Russell T. Cost-Utility Analysis of HomeBased Telerehabilitation Compared With Centre-Based Rehabilitation in Patients With Heart Failure. Heart Lung Circ. 2018; 28(12),1795-803. doi: 10.1016/j.hlc.2018.11.010. 
13. Kim JS, Yun D, Kim HJ, Ryu HY, Oh J, Kang SM. Need Assessment for Smartphone-Based Cardiac Telerehabilitation. Healthc Inform Res, 2018;.Oct, 24(4):283-91. doi: 10.4258/hir.2018.24.4.283.

14. Long L, Anderson L, Dewhirst AM, He J, Bridges C, Gandhi M, Taylor RS. Exercise-based cardiac rehabilitation for adults with stable angina. Cochrane Database of Systematic Reviews. 2018; 2. Art. No.: CD012786. DOI: 10.1002/14651858.CD012786.pub2.

15. Maddison R, Rawstorn JC, Stewart RAH, Benatar J, Whittaker R, Rolleston A, Jiang Y, Gao L, Moodie M, Warren I, Meads A, Gant N. Effects and costs of real-time cardiac telerehabilitation: randomised controlled noninferiority trial. Heart. 2019; 105(2),122-9. doi: 10.1136/heartjnl-2018-313189.

16. Peng X, Su Y, Hu Z, Sun X, Li X, Dolansky MA, Qu M, Hu X. Home-based telehealth exercise training program in Chinese patients with heart failure: A randomized controlled trial. 2018; 97 (35). e12069. doi: 10.1097/ MD.0000000000012069.

17. Peretti A, Amenta F, Tayebati SK, Nittari G, Mahdi SS. Telerehabilitation: Review of the State-of-the-Art and Areas of Application. JMIR Rehabil Assist Technol.2017; 21;4(2):e7. doi: 10.2196/rehab.7511.

18. Saygin Aydin N, Ceyhan Dogan S, Yucel H, Zorlu A, Yilmaz MB. Effects of hospital-based cardiac rehabilitation and home-based exercise program in patients with previous myocardial infarction. Cumhuriyet Medical Journal. 2018; 40, 746-54.

19. Tian Y, Deng P, Li B, Wang J, Li J, Huang Y, Zheng Y. Treatment models of cardiac rehabilitation in patients with coronary heart disease and related factors affecting patient compliance Rev. Cardiovasc. Med. 2019; 20(1) 2733 DOI: $10.31083 / \mathrm{j} . \mathrm{rcm} .2019 .01 .53$

20. Frontera WR, Bean JF, Damiano D, Ehrlich-Jones L, Fried-Oken M, Jette A, Jung R, Lieber RL, Malec JF, Mueller MJ, Ottenbacher KJ, Tansey KE, Thompson A. Rehabilitation research at the national institutes of health. Neurorehabilitation and Neural Repair 2017; 31: 304-14.

21. Frontera WR, Bean JF, Damiano D, Ehrlich-Jones L, Fried-Oken M, Jette A, Jung R., Lieber RL, Malec JF, Mueller MJ, Ottenbacher KJ, Tansey KE, Thompson A. Rehabilitation research at the national institutes of health moving the field forward (executive summary). Rehabilitation Psychology.2017; 62:387-96.

\section{Literature}

1. Ipatov AV, Lysunets OM, Khaniukova II, Tkachenko IV, Ovdii OM, Zubko IM. Primary disability due to leading diseases of the circulatory system in Ukraine. Bukovynskyi medychnyi visnyk. 2017; 21 (2):197-202.

2. Kovalenko VN, Dolzhenko MN, Nesukai EH, Dyachenko YS. Comparative characteristics of the prevention of cardiovascular diseases in Ukraine and Europe according to EUROASPIRE IV: hospital line. Arterialnaya gypertenziya. 2015; 5(43):57-61

3. Kornus $\mathrm{OH}$, Kornus AO, Shyshuk VD, Lohvyn HO. Primary morbidity and prevalence of diseases of the circulatory system and their role as causes of mortality in the Sumy region.[Internet]. Scientific Notes of Sumy State Pedagogical University. Geographical Sciences. 2020; 2 (1): 97-111. Available from: http://scinotesgeo.at.ua/ Vol2_Iss1/Kornus_O.H-Kornus_A.O-Shyshchuk_V.D-Lohvyn_H.O-Pri.pdf. DOI: doi.org/10.5281/zenodo.3661431

4. Korchynskyi VS. Cardiorehabilitation: current status and development priorities. Visnyk Vinnytskoho medychnoho universytetu. 2015; 1 (19): 244-7.

5. Khyts A. Ischemic heart disease: diagnosis and treatment. [Internet]. Access mode: https://www.umj.com.ua/ article/163681/ishemichna-hvoroba-sertsya-diagnostika-ta-likuvannya

6. Shaposhnikov DI, Radomskyi OV. Bielikova IV, Kostrikov AV. Analysis of the epidemiological situation regarding diseases of the circulatory system in Ukraine and Pakistan. 2019. [Internet]. Access mode: http://elib.umsa.edu.ua/ bitstream/umsa/10304/1/Analysis_of_the_epidemiological_situation.pdf

7. Shved MI, Levytska LV. Modern strategies for treatment and rehabilitation of patients with myocardial infarction. Kyiv. 2015. 152 p.

8. Bravo-Escobar R., Gonzalez-Represas A, Gomez-Gonzalez AM., Montiel-Trujillo A, Aguilar-Jimenez R, Carrasco-Ruiz R, Salinas-Sanchez P. Effectiveness and safety of a homebased cardiac rehabilitation programme of mixed surveillance in patients with ischemic heart disease at moderate cardiovascular risk: A randomised, controlled clinical trial. BMC Cardiovasc Disord 2017. 17: 1-11.

9. Chan C, Yamabayashi C, Syed N, Kirkham A, Camp PG. Exercise Telemonitoring and Telerehabilitation Compared with Traditional Cardiac and Pulmonary Rehabilitation: A Systematic Review and Meta-Analysis. Physiother Can. 2016. 68(3): 242-51.

10. Dorje T, Zhao G, Scheer A, Tsokey L, Wang J, Chen Y, Tso K, Tan BK, Ge J, Maiorana A. SMARTphone and social media-based cardiac rehabilitation and secondary prevention (SMART-CR/SP) for patients with coronary heart disease in China: a randomised controlled trial protocol. BMJ Open. 2018; 8, 1-9.

11. Gensini GF, Alderighi C, Rasoini R, Mazzanti M, Casolo G. Value of Telemonitoring and Telemedicine in Heart Failure Management. Card Fail Rev.2017; 3(2),116-121. doi: 10.15420/cfr.2017:6:2.

12. Hwang R, Morris NR, Mandrusiak A, Bruning J, Peters R, Korczyk D, Russell T. Cost-Utility Analysis of HomeBased Telerehabilitation Compared With Centre-Based Rehabilitation in Patients With Heart Failure. Heart Lung Circ. 2018; 28(12),1795-803. doi: 10.1016/j.hlc.2018.11.010.

13. Kim JS, Yun D, Kim HJ, Ryu HY, Oh J, Kang SM. Need Assessment for Smartphone-Based Cardiac Telerehabilitation. Healthc Inform Res, 2018;.Oct, 24(4):283-91. doi: 10.4258/hir.2018.24.4.283. 
14. Long L, Anderson L, Dewhirst AM, He J, Bridges C, Gandhi M, Taylor RS. Exercise-based cardiac rehabilitation for adults with stable angina. Cochrane Database of Systematic Reviews. 2018; 2. Art. No.: CD012786. DOI: 10.1002/14651858.CD012786.pub2.

15. Maddison R, Rawstorn JC, Stewart RAH, Benatar J, Whittaker R, Rolleston A, Jiang Y, Gao L, Moodie M, Warren I, Meads A, Gant N. Effects and costs of real-time cardiac telerehabilitation: randomised controlled noninferiority trial. Heart. 2019; 105(2),122-9. doi: 10.1136/heartjnl-2018-313189.

16. Peng X, Su Y, Hu Z, Sun X, Li X, Dolansky MA, Qu M, Hu X. Home-based telehealth exercise training program in Chinese patients with heart failure: A randomized controlled trial. 2018; 97 (35). e12069. doi: 10.1097/ MD.0000000000012069.

17. Peretti A, Amenta F, Tayebati SK, Nittari G, Mahdi SS. Telerehabilitation: Review of the State-of-the-Art and Areas of Application. JMIR Rehabil Assist Technol.2017; 21;4(2):e7. doi: 10.2196/rehab.7511.

18. Saygin Aydin N, Ceyhan Dogan S, Yucel H, Zorlu A, Yilmaz MB. Effects of hospital-based cardiac rehabilitation and home-based exercise program in patients with previous myocardial infarction. Cumhuriyet Medical Journal. 2018; 40, 746-54.

19. Tian Y, Deng P, Li B, Wang J, Li J, Huang Y, Zheng Y. Treatment models of cardiac rehabilitation in patients with coronary heart disease and related factors affecting patient compliance Rev. Cardiovasc. Med. 2019; 20 (1) 2733 DOI: 10.31083/j.rcm.2019.01.53

20. Frontera WR, Bean JF, Damiano D, Ehrlich-Jones L, Fried-Oken M, Jette A, Jung R, Lieber RL, Malec JF, Mueller MJ, Ottenbacher KJ, Tansey KE, Thompson A. Rehabilitation research at the national institutes of health. Neurorehabilitation and Neural Repair 2017; 31: 304-14.

21. Frontera WR, Bean JF, Damiano D, Ehrlich-Jones L, Fried-Oken M, Jette A, Jung R., Lieber RL, Malec JF, Mueller MJ, Ottenbacher KJ, Tansey KE, Thompson A. Rehabilitation research at the national institutes of health moving the field forward (executive summary). Rehabilitation Psychology.2017; 62:387-96.

Надійшла 24.02.2020

\section{Інформація про авторів}

Костенко Владислав Павлович

https://orcid.org//0000-0001-8252-1245

kostenkovlad1995@gmail.com

Балаж Марія Степанівна, https://orcid.org/ /0000-0002-6710-9567 balazhms@gmail.com

Національний університет фізичного виховання і спорту України, 03150, Київ, вул. Фізкультури, 1

\section{Information about the authors}

Kostenko Vladislav

https://orcid.org/ /0000-0001-8252-1245

kostenkovlad1995@gmail.com

Balazh Mariia

https://orcid.org/ /0000-0002-6710-9567

balazhms@gmail.com

National University

of Ukraine on Physical Education and Sport,

03150, Kyiv, Fizkul'tury str., 1. 